\title{
Theory of University Education Culture
}

\author{
KeKe LIU \\ University of Jinan, Shandong 250022, China
}

\begin{abstract}
Starting from the perspective of cultural talent cultivation, this paper discusses the reason why the inheritance and innovation of culture become the fourth function of college education; the great value the college cultural construction possesses in talent cultivation; the restrictive elements of college talent cultivation from the perspective of culture; and also the leading role of college culture in college talent cultivation.
\end{abstract}

KEYWORD: College Culture; Talent Cultivation; Restriction; Leading

To cultivate talents, the first task of higher education is to figure out what kind of people to cultivate. It not only needs to cultivate professional personnel, but also has to cultivate some intellectual groups. Because it is these intellectual power who form the nucleus of our society and influence social culture as well as the development of the whole society. Therefore, college students not only need to master solid professional knowledge, but also have to attain higher cultural appreciation. What's more, these students are also required to build the right world view and life outlook as well as gracious ideology and social responsibility. All these form the main task and role of humanistic and social science education.[1]

\section{THE ORIGIN OF COLLEGE CULTURE FUNCTION}

For a long time, talent cultivation, scientific research and social service have been widely regarded as the three major functions of university. The earliest university of the world was the Bologna University in Italy, which was founded in 1088. While in China, the ancient government had founded the Imperial College. For example, in the Tang Dynasty, there were professors and doctors in these colleges. However, the Imperial College had been a kind of exam-oriented education, aiming at the Imperial Examination and enabling students to walk onto their official career instead of instilling knowledge and developing capacity. The Bologna University of Italy is a scholastic university and they firstly propose the notion of instilling knowledge and developing capacity. Therefore, the contents of college education in Middle Ages focused on theology, law, medicine and literature, which means that the main function of university is teaching and training. In 1810, Humboldt of German established the Berlin University, which endowed the college education with a new function, that is, combining teaching and researching. The scientific research function demanded corresponding academic spirit, academic freedom and academic autonomy, which is called Humboldt Spirit. And then in the 1930s, the American universities, represented by the University of Wisconsin and the Cornell University, came up the idea that "He who steps on cow dung is a real good professor", which implies the social service function of university. College education shoulders the responsibility of training talents and serving the society. Thus, the three major functions of university had finally been builded, talent cultivation, scientific research and social service.

Stepping into the 21st century, especially after "The 911 Event", universal changes have taken place in higher education across the world. Firstly, the internationalization level and the diversification trend develop at a very high speed, which is manifested by the appearance of the international evaluation standard. Secondly, universities make use of its unique advantages to promote the communication and infusion of different cultures, which helps to remove the conflicts between different cultures and promote the cultural harmony of the world. "Global Village" has formed. In April, 2011, General Secretary Hu Jintao put forward that 
the inheritance and innovation of culture should rank as the fourth function of university in the assembly of Tsinghua University's 100th anniversary.

Ranking the inheritance and innovation as the fourth function of university is General Secretary $\mathrm{Hu}$ Jintao"s summary for college and higher education rule. It plays a very significant role for comprehensively improving the quality of higher education and enhancing cultural construction. Technological innovation plays the same role as the inheritance and innovation of culture and should have the same status. As far as their values are concerned, the inheritance and innovation of culture provides direction and lifestyle for our society and therefore it stands on the ideology level of the Superstructure while the technological innovation provides driving power for our society and therefore it stands on the productivity level. These two aspects are thus like the rudder and the engine of a steamship that are both very important. The expansion of the fourth of university presents a higher and newer demand for higher education. And at the same time, it enriches and develops the connotation of college strategic management. University is the engine and "The Axis Organization "of social progress, and also the thinking bank and the brain trust for seizing the direction of social development.

\section{THE SIGNIFICANCE OF COLLEGE CULTURE ON TALENT CULTIVATION}

Talent Cultivation of higher education becoming state duty and national duty. According to the research and predication of He Chuanqi and several other experts of Chinese Academy of Science, the sixth scientific and technological revolution is now walking toward us. In the past 500 years, there have been five scientific and technological revolution taking place one by one, including two scientific revolution and three technological revolution, with the first scientific revolution marked by Newton's mechanics, the second quantum theory and relativity, and the first technological revolution marked steam engineer and machinery, the second electricity and internal combustion engine, and the third electric computer and internet. Chinese had lost the opportunity to take part in four of the five revolutions, which made China's international standing glide rapidly. However, thanks to the fifth revolution, China carried on the largest scientific development plan and acquired a lot of achievements. Though China's international standing rose, we had not produced any great scientific break-through and technical invention of world influence, which was then judged by others as "only average performance", "China is a follower, one who has not made any excellent performance". Experiences and lessons of history tells us that scientific and technological revolution has immediate impact on the rise and fall of a nation as well as its position in global competition pattern. Thus at the dawn of the sixth revolution, China comes to a cross once again. Seizing this opportunity means that it is possible to realize "national rejuvenation", otherwise, we may be on average performance again. In this sense, college talent cultivation has not been an ordinary duty, rather it is state duty and national duty.

\section{THE FORMING OF RIGHT VALUE ORIENTATION AND THE PROGRESS OF SOCIETY RELYING ON COLLEGE EDUCATION}

As the Reform and Opening deepens, economic and social structure change profoundly, correspondingly bringing profound alternations to interest pattern and ideology. With the increasingly prominent conflicts and problems, social stability and national peace are now facing big challenges. Suppose the ethical pursuits and value orientation that our whole nation are seeking after are only "Delicate Egoism", "Parochial Extremism", "Vulgar Consumerism", "Sophistical Relativism" and "Unanalytical Scepticism", what hope can there be?

The forming of right value orientation and the progress of society mainly rely in college education. The development history of society and college have already proved that college impose a profound, lasting and stable influence on society, which can be explained through the development law of human beings, culture as well as human society. Therefore, the development of human himself means cultural development in essence, which can influence human beings' development and progress in a very deep sense. As the holy land of producing culture and guiding thoughts, college is the paradise of civilization. It delivers civilized faith, imparts civilized knowledge and cultivates civilized people.

\section{COLLEGE CULTURE'S LEADING ROLE IN TALENT CULTIVATION}

University is talent-cultivation-based cultural organization, with a distinctive function, just as Minister Yuan Guiren points out that "To some extent, university is culture. The educating and teaching process of a university is in essence a purposed and planned cultural process. The generally called education talent cultivation, management talent cultivation, serving talent cultivation and environment talent cultivation are 
actually cultural talent cultivation". College culture exerts a subtle and profound influence on talent cultivation. Meanwhile, college is the most creative academic community, shouldering the responsibility of exploring the truth, developing technology. It is safe to say that cultural innovation and modern university system construction play a decisive role on the creativity of the college community. [2]Therefore, college culture plays a leading role in the process of cultivating talents.

\section{THE CORE COMPETITIVE FORCE IN ACHIEVING THE COLLEGE TALENT CULTIVATION GOAL IS COLLEGE CULTURE}

In the past, connotation development refers to data in the aspects of subjects, researches, and talent cultivation. Actually, these data are only indexes for evaluating colleges' connotation development. No matter it is talent cultivation, scientific research or social service, cultural construction has permeated in colleges' functions from the beginning to the end. Enforcing cultural construction itself is an important constituent part of college connotation development. At the same time, it provides a significant guarantee for promoting talent cultivation, scientific research, social service, for forging teachers and students' characters. The achievement of college connotation development lies in teachers and students' values, professional ethics, moral integrity, in their inner aspiration and faith, which are the real inherent development of higher education. The connotation development of higher education at last forms cultural highland of the whole society and then guides social development.
6 COLLEGE COMMUNITY'S VALUES ARE THE EVERLASTING DRIVING POWER IN CULTIVATING COLLEGE TALENT

College culture is in essence a culture of the intellectuals. The college community composed of these intellectuals possesses not only knowledge, but also strong social responsibility and a sense of mission for the development of our society and nation. Most people regard university as "the symbol of integral human dignity", which implies that college teachers and students' aspiration, moral integrity and faith should exceed that of general public. In such a way, they can guide the science, people's thinking, social atmosphere, and further more systematical innovation and social progress.

College culture, as a long-accumulated thinking pattern and value system, plays the role of leading, limiting, integrating and encouraging. College culture can arouse a sympathy for the college between college members, which afterwards stimulates their sense of promising for faith and values that surpass themselves. It brings out the functional behaviors that help to achieve the organizing goal and then enforce the effectiveness of college strategic implementation. [3] Cultural force can be seen everywhere in the college talent cultivation. Therefore, college cultural construction plays a very important role in achieving the goal of college talents cultivation.

\section{REFERENCES}

[1] Gu Mingyuan, 2011. Promote the Innovation of Culture, Highlight the Education of Talents' Pursuit of Truth, China Higher Education 10: 12.

[2] Hu Xianzhang, 2010, Reflections on the Construction of College Culture, China Higher Education 8: 22-24,

[3] Wei Hailiang, 2008, Adaptation and Coordination: Explore the Relation between College Strategic Management and College Culture, Liaoning Higher Education 2: 19-22. 